\title{
PERIOPERATIVE CHANGES IN LYMPHOCYTE SUBPOPULATIONS IN PATIENTS UNDERGOING SURGERY FOR COLORECTAL CANCER
}

\author{
Mateusz Rubinkiewicz ${ }^{1}$, Izabela Siemińska ${ }^{2}$, Piotr Małczak ${ }^{1,3}$, Piotr Major ${ }^{1,3}$, \\ Jarosław Baran ${ }^{2}$, Andrzej Budzyński ${ }^{1,3}$ and Michał Pędziwiatr ${ }^{1,3}$
}

${ }^{1} 2^{\text {nd }}$ Department of General Surgery, Jagiellonian University Medical College, Krakow, Poland; ${ }^{2}$ Department of Clinical Immunology, Institute of Pediatrics, Jagiellonian University Medical College, Kraków, Poland;

${ }^{3}$ Centre for Research, Training and Innovation in Surgery (CERTAIN Surgery), Krakow, Poland

SUMMARY - Surgical procedure has immense impact on the immune balance. However, little is known about perioperative changes in T regulatory and Th17 lymphocyte subpopulations in patients undergoing colorectal resection. Patients with resectable colon cancer were enrolled in the study. Blood samples were obtained on two occasions, i.e. before the procedure and two days after the surgery. We also recruited a control group of young, healthy individuals. Lymphocyte subpopulations were analyzed with the use of flow cytometry. Investigated subpopulations consisted of total lymphocyte count, CD4+, CD8+, T regulatory Foxp3+ (Tregs), Th17 lymphocytes and white blood cell $(\mathrm{WBC})$ count. There were significant differences in immune cell levels before and after the surgery. Reduction was recorded in the CD4+, CD8+, Tregs and total lymphocyte counts ( $\mathrm{p}=0.002, \mathrm{p}=0.01$, $\mathrm{p}=0.008$ and $\mathrm{p}=0.001$, respectively). Increase was observed in total WBC and Th17 cells, however, Th17 lymphocytes did not reach statistical significance ( $\mathrm{p}=0.01$ and $\mathrm{p}=0.5$, respectively). In conclusion, surgical intervention caused changes in all lymphocyte subpopulations investigated in patients undergoing surgery for colorectal cancer. However, it seemed to be an effect of perioperative trauma. Further studies are needed to investigate the impact of surgical intervention on lymphocyte subpopulations.

Key words: Lymphocyte subsets; T-lymphocytes, regulatory; Th17 cells; Lymphocyte count; Colorectal surgery

\section{Introduction}

Colorectal cancer affects 1.4 million people worldwide, causing 694,000 deaths. Novel treatment methods are improving long-term survival; however, the outcomes are still not satisfying. In the vast majority of cases, colorectal cancers are treated surgically followed by adjuvant therapy, which currently includes usage of monoclonal antibodies such as anti-VEGF bevaci-

Correspondence to: Michat Pędziwiatr, $M D, P h D, 2^{\text {nd }}$ Department of General Surgery, Jagiellonian University Medical College, Kopernika 21,31-501 Kraków, Poland

E-mail: michal.pedziwiatr@uj.edu.pl

Received October 24, 2018, accepted December 10, 2018 zumab. There is continuing search for optimal therapy and currently involves checkpoint immunotherapies. Cancer development is accompanied by tissue inflammation. The tumor is infiltrated with different cells of the immune system. The composition of immune cells in peripheral blood of patients with colorectal cancer is under constant investigation ${ }^{1}$. Interaction between different subtypes of immune cells seems to have crucial influence on overall survival ${ }^{2}$. A special role is assigned to regulatory lymphocytes with expression of Foxp3+ molecule (Tregs) ${ }^{3}$. High concentration of Tregs in tumor tissue was demonstrated to worsen clinical outcome in pancreatic and hepatobiliary neoplasms ${ }^{4}$. Surgical procedure has a huge impact on immune bal- 

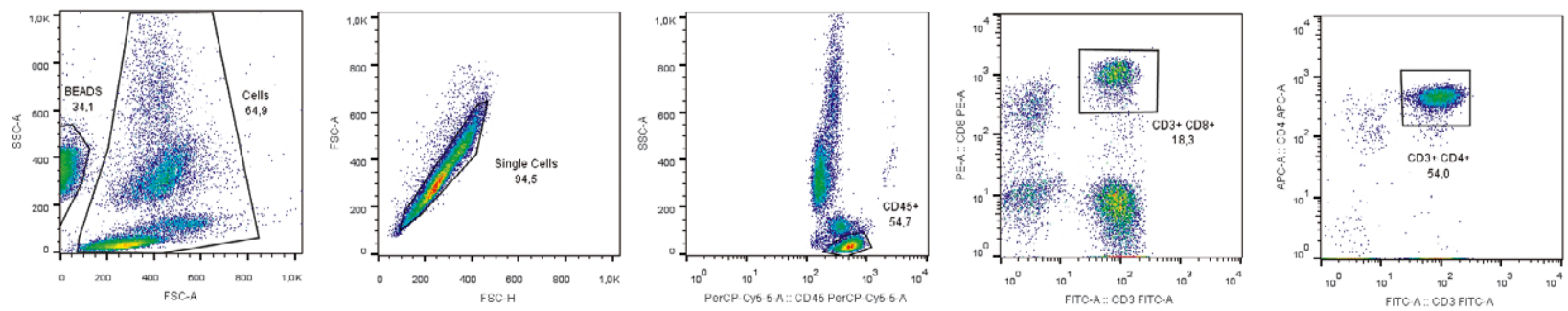

Fig. 1. Gating strategy for $C D 3+C D 4+$ and $C D 3+C D 8+T$ cell identification in peripheral blood of colorectal cancer patients and healthy individuals.
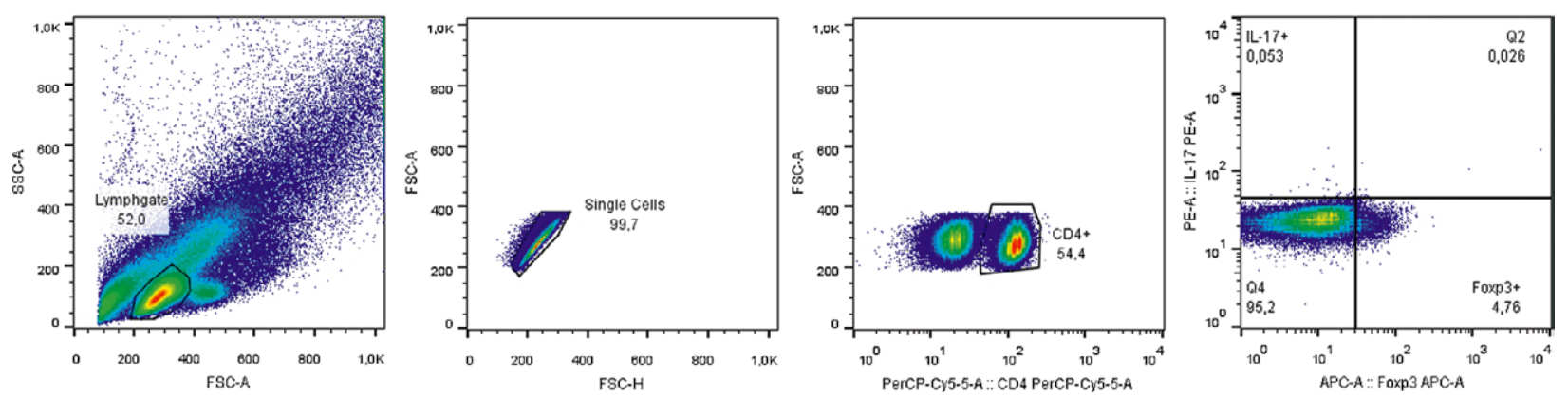

Fig. 2. Gating strategy for CD4+ Foxp3+ Tregs and CD4+IL-17+Th17 cell identification in peripheral blood of colorectal cancer patients and healthy individuals.

ance ${ }^{5,6}$. However, studies focusing on perioperative changes in T regulatory and Th17 lymphocytes subpopulations are scarce.

The aim of the study was to assess the number of lymphocyte subtypes in perioperative period in patients with colon cancer.

\section{Materials and Methods}

Patients with resectable colon cancer were enrolled in the study. Patients had to fulfill the following inclusion criteria: age above 18 years, histologically proven colon cancer, and resectable lesion. Exclusion criteria were as follows: patients with distant metastases, patients with immune deficiencies, patients with colon cancer associated with inflammatory bowel disease, patients who had been treated with neoadjuvant chemo- or radiotherapy, and patients requiring blood transfusion during surgical procedure or in the postoperative course. The inclusion criteria were met by 14 patients. Blood samples were obtained on two occasions, i.e. before the procedure and two days after the surgery. We also recruited control group consisting of young, healthy subjects. Lymphocyte subpopulations were analyzed with the use of flow cytometry.

\section{Isolation of peripheral blood mononuclear cells}

Peripheral blood mononuclear cells (PBMC) were isolated by standard Ficoll-Paque (Pharmacia, Uppsala, Sweden) density gradient centrifugation from whole peripheral blood samples collected from colorectal cancer patients and healthy control subjects into EDTA containing tubes (Vacutainer System, Becton Dickinson, San Jose, CA, USA).

\section{Determination of absolute number of CD3+CD4+ cells}

Whole peripheral blood samples $(25 \mu \mathrm{L})$ were incubated in TruCount tubes (BD Biosciences, BD Biosciences, San Jose, CA, USA) with the following monoclonal antibodies: anti-CD3-FITC, anti-CD8-PE, anti-CD45-PerCP and anti-CD4-APC (BD Multitest TM, BD Biosciences, BD Biosciences, San Jose, CA, USA) for 30 minutes at $4{ }^{\circ} \mathrm{C}$. Then the samples were treated with $250 \mu \mathrm{L}$ of FACS Lysing Solution (BD Biosciences, San Jose, CA, USA) and after erythrocyte lysis, 10,000 of $\mathrm{CD} 3{ }^{+} \mathrm{CD} 4{ }^{+}$cells with beads was acquired on a FACSCanto flow cytometer using FACSDiva software. The absolute numbers of $\mathrm{CD}^{+}{ }^{+} \mathrm{CD}^{+}{ }^{+}$and $\mathrm{CD} 3{ }^{+} \mathrm{CD} 8{ }^{+}$lymphocytes were calcu- 
lated on the basis of beads and lymphocyte counts, according to the formula below:

$\left[\right.$ (number of events in region containing $\mathrm{CD}^{+} \mathrm{CD}^{+}$ or $\mathrm{CD}^{+}{ }^{+} \mathrm{CD} 8^{+}$cells) / (number of events in absolute count bead region)] x [(number of beads per test) / (test volume) $]=$ absolute number of $\mathrm{CD}^{+}{ }^{+} \mathrm{CD}^{+}{ }^{+}$or $\mathrm{CD} 3^{+} \mathrm{CD} 8{ }^{+}$cells.

\section{Determination of Treg and Th17 cell count}

For Tregs and Th17 cell analysis, PBMC were stained using Th17/Treg Human Phenotypic Kit (BD PharmingenTM, Canada) with the following mAbs: anti-CD4-PerCP, anti-IL-17A-PE and antiFoxp3APC, according to the manufacturer's instructions. In parallel, a control sample was prepared to determine nonspecific cell binding of antibodies (isotype control). Samples were analyzed in FACSCanto flow cytometer using FACSDiva software. The absolute numbers of Treg cells were calculated on the basis of the CD4 ${ }^{+}$Foxp $^{+}$, whereas Th17 cells were calculated as CD4+IL-17A+cells both as percentage of $\mathrm{CD}^{+}$and absolute number of $\mathrm{CD}^{+}{ }^{+} \mathrm{CD} 4{ }^{+}$cells. Gating strategies are presented in Figures 1 and 2.

\section{Statistical analysis and ethical consideration}

All data were analyzed with Statistica version 13.0 PL (StatSoft Inc., Tulsa, OK, USA). The results were expressed as mean and standard deviation (SD) and median. The $\chi^{2}$-test of independence was used to evaluate categorical variables. The Shapiro-Wilk test was used to check for normal distribution of data and the Student's $t$ test was used for normally distributed quantitative data. For non-normally distributed quantitative variables, the Mann-Whitney $U$ test was used. The level of statistical significance was set at $\mathrm{p}<0.05$.

All procedures were performed in accordance with ethical standards of the 1964 Declaration of Helsinki and its later amendments (Fortaleza 2013). The study was approved by the local Ethics Committee. Each patient signed an informed consent prior to inclusion in the study.

\section{Results}

Fourteen patients were eventually included in the analysis. Patient characteristics are presented in Table 1. Preoperative counts of CD4+, CD8+ and Tregs were
Table 1. Patient characteristics

\begin{tabular}{|l|l|}
\hline \multicolumn{2}{|c|}{ General characteristics } \\
\hline Age (years) & $66(38-80)$ \\
Weight $(\mathrm{kg})$ & $73.5(55-97)$ \\
Height $(\mathrm{cm})$ & $165(150-185)$ \\
Length of stay (days) & $6(3-11)$ \\
Morbidity & 2 \\
1-year recurrence & 4 \\
\hline \multicolumn{2}{|c|}{ Tumor localization } \\
\hline Localization & Number of patients \\
\hline Cecum & 4 \\
Ascending colon & 1 \\
Transverse colon & 0 \\
Descending colon & 1 \\
Sigmoid colon & 2 \\
Sigmoid rectal junction & 6 \\
\hline \multicolumn{2}{|c|}{ Tumor stage } \\
\hline Stage & Number of patients \\
\hline I & 2 \\
IIA & 9 \\
IIIB & 2 \\
IIIC & 1 \\
\hline
\end{tabular}

Table 2. Baseline number of immune cells in cancer group and control group

\begin{tabular}{|l|l|l|l|}
\hline Cell type & Control group & Cancer group & $\mathrm{p}$ value \\
\hline CD4+ & $672(247-975)$ & $818(150-1491)$ & 0.78 \\
\hline CD8+ & $320(120-611)$ & $336(49-998)$ & 0.98 \\
\hline T reg & $\begin{array}{l}47.8 \\
(14.5-73.0)\end{array}$ & $\begin{array}{l}47.16 \\
(12.33-109.72)\end{array}$ & 0.84 \\
\hline Th 17 & $1.72(0.74-5.28)$ & $0.17(0-4.47)$ & 0.001 \\
\hline
\end{tabular}

similar in the cancer group and healthy controls ( $\mathrm{p}=0.78, \mathrm{p}=0.98$ and $\mathrm{p}=0.94$, respectively). Only Th17 count was significantly higher in healthy controls than in cancer group ( $\mathrm{p}=0.001$ ) (Table 2).

All patients had colorectal cancer confirmed on postoperative pathological examination. There were no statistical differences in tumor staging and immune cell count $(\mathrm{CD} 4+\mathrm{p}=0.92 ; \mathrm{CD} 8+\mathrm{p}=0.96$; Th17 $\mathrm{p}=0.42$; Treg $\mathrm{p}=0.95)$. No statistical significance was found regarding local recurrence at 1-year observation (CD4+ $\mathrm{p}=0.62 ; \mathrm{CD} 8+\mathrm{p}=0.72 ;$ Th17 $\mathrm{p}=0.25$; Treg $\mathrm{p}=0.72$ ). 
Table 3. Number of immune cells before and after surgery

\begin{tabular}{|l|l|l|l|}
\hline Cell type & $\begin{array}{l}\text { Number before surgery } \\
\text { (median, range) }\end{array}$ & $\begin{array}{l}\text { Number after surgery } \\
\text { (cells/uL, median, range) }\end{array}$ & p value \\
\hline Cd4+ (cells/uL) & $818(150-1491)$ & $321(160-986)$ & 0.002 \\
Cd8+ (cells/uL) & $336(49-998)$ & $260(24-992)$ & 0.01 \\
Treg $($ cells/uL) & $47.16(12.33-109.72)$ & $27.1(9.44-123.25)$ & 0.008 \\
Th17 (cells/uL) & $0.17(0-4.47)$ & $0.33(0-10)$ & 0.5 \\
WBC $\left(10^{\wedge} 3 / \mathrm{mm}^{3}\right)$ & $4.7(2.4-10.3)$ & $8.1(4.9-13.3)$ & 0.01 \\
Lymphocyte count $\left(10^{\wedge} 3 / \mathrm{mm}^{3}\right)$ & $1.35(0.4-3.2)$ & $1.1(0.3-2.3)$ & 0.01 \\
\hline
\end{tabular}

There were significant differences in immune cell levels before and after the surgery. We observed reduced counts of CD4+, CD8+, Tregs and total lymphocyte $(\mathrm{p}=0.002, \mathrm{p}=0.01, \mathrm{p}=0.008$ and $\mathrm{p}=0.001$, respectively). We observed an increase in total WBC and Th17 cell count; however, Th17 lymphocytes did not reach statistical significance $(\mathrm{p}=0.01$ and $\mathrm{p}=0.5$, respectively). The results are summarized in Table 3.

\section{Discussion}

In our study, we found that cancer patients had a significantly lower level of Th17 lymphocytes than healthy controls. However, many authors report increased levels of Th17 cells in colorectal cancer patients $^{7,8}$. On the contrary, Ling et al. obtained results similar to ours. Not only were the levels of Th17 cells higher in healthy controls than in colorectal cancer patients, but also the number of Th17 cells correlated inversely with colorectal cancer stage ${ }^{9}$. Although Th17 lymphocytes are believed to enhance anti-tumor immunity, they may induce adverse reaction ${ }^{10}$. Th17 cells, as well as Tregs, accumulate in premetastatic niche, where they produce pro-tumorigenic factors such as VEGF-A ${ }^{11}$. Moreover, Amicarella et al. report that Th17 cells may secrete pro- and anti-tumorigenic factors, depending on their localization, thus the final role of Th17 cells requires further investigation ${ }^{12}$. Lee et al. report that higher levels of Th17 might be useful as markers of lymph node invasion ${ }^{13}$. In our group, only two patients had lymph node invasion, thus it was too small to verify this hypothesis.

Surgical removal of the tumor changed the composition of immune cells. We observed a significant increase in Th17 cell count, in comparison with the figure recorded in healthy controls. All of our patients received minimally invasive approach, thus their immune system might have been less affected. However, Ling et al. obtained similar results, i.e. colorectal cancer resection caused Th17 lymphocyte count elevation'. An interesting study by Zhang et al. investigated the number of Tregs and NK cells in patients undergoing video-assisted thoracoscopic surgery (VATS) lobectomy or classic thoracotomy due to non-small cell lung carcinoma. In their research, the number of Tregs was lower after than before the surgery in both groups. However, at 90-day follow up, patients having undergone VATS lobectomy had lower Tregs count than thoracotomy group ${ }^{14}$. This may favor minimally invasive approach in cancer surgery. All our patients were operated with minimally invasive techniques, which are believed to cause less trauma to the patient. However, large studies including meta-analyses found no difference in long-term oncologic outcomes comparing open surgery and laparoscopic approach ${ }^{15-17}$. A small number of researches comparing open and laparoscopic surgery may stimulate novel study designs for perioperative immunoregulation.

Removal of the tumor also caused drop in the number of Foxp3 regulatory lymphocytes. However, their number after the surgery was lower than in healthy controls. The role of Tregs remains controversial. It is worth mentioning that we also found an increased number of Foxp3 cells in tumor microenvironment in early stages of colorectal carcinoma development, such as adenoma with high-grade dysplasia ${ }^{18}$. Waniczek et al. identified intense Tregs infiltration in tumor stroma as an independent factor of shorter disease-free survival and overall surviva ${ }^{19}$. As mentioned before, lymphocyte infiltration in tumor environment rich in Foxp3 lymphocytes is a negative prognostic factor in many neoplasms. On the contrary, a recent meta-analysis including 3811 patients assessed the 
prognostic value of Foxp3 lymphocytes in colorectal cancer microenvironment. Tregs infiltration in tumor stroma and epithelium was found to correlate positively with 1-, 3-, 5- and 10-year survival. However, this finding did not refer to disease-free surviva ${ }^{20}$. The study was also focused on tumor microenvironment, and Tregs number in peripheral blood was not assessed.

We are also aware that our study had some limitations. Firstly, study group had only 14 patients. More cases would significantly increase the study value and statistical significance of our results. Long-term control of lymphocyte subtypes would also be valuable, however, most of our patients underwent adjuvant chemotherapy or radiotherapy, which severely interferes with immune cell composition. Nevertheless, there are some data supporting the hypothesis that radiotherapy does not affect Tregs population ${ }^{21}$.

\section{Conclusion}

Surgical intervention caused changes in all lymphocyte subpopulations investigated in patients undergoing surgery for colorectal cancer. However, it seemed to be the effect of perioperative trauma. Additional studies are needed to investigate the impact of surgical intervention on lymphocyte subpopulations.

\section{References}

1. Mei Z, Shi L, Wang B, Yang J, Xiao Z, Du P, Wang Q, Yang W. Prognostic role of pretreatment blood neutrophil-to-lymphocyte ratio in advanced cancer survivors: a systematic review and meta-analysis of 66 cohort studies. Cancer Treat Rev. 2017; 58:1-13. doi:10.1016/j.ctrv.2017.05.005.

2. Wu Q, Hu T, Zheng E, Deng X, Wang Z. Prognostic role of the lymphocyte-to-monocyte ratio in colorectal cancer, Medicine (Baltimore). 2017;96:e7051. doi:10.1097/MD.0000000000007051.

3. Lee W-S, Park S, Lee WY, Yun SH, Chun H-K. Clinical impact of tumor-infiltrating lymphocytes for survival in stage II colon cancer. Cancer. 2010;116:5188-99.

doi:10.1002/cncr.25293.

4. Kobayashi N, Hiraoka N, Yamagami W, Ojima H, Kanai Y, Kosuge T, Nakajima A, Hirohashi S. FOXP3+ regulatory T cells affect the development and progression of hepatocarcinogenesis. Clin Cancer Res. 2007;13:902-11. doi:10.1158/10780432.CCR-06-2363.

5. Slade MS, Simmons RL, Yunis E, Greenberg LJ. Immunodepression after major surgery in normal patients. Surgery. 1975;
78:363-72. http://www.ncbi.nlm.nih.gov/pubmed/1098195 (accessed July 8, 2018).

6. Hansbrough JF, Bender EM, Zapata-Sirvent R, Anderson J. Altered helper and suppressor lymphocyte populations in surgical patients. A measure of postoperative immunosuppression. Am J Surg. 1984;148:303-7. http://www.ncbi.nlm.nih.gov/ pubmed/6236703 (accessed July 8, 2018).

7. LiX, Wang Y, Han C, Li P, Zhang H. Colorectal cancer progression is associated with accumulation of Th17 lymphocytes in tumor tissues and increased serum levels of interleukin-6. Tohoku J Exp Med. 2014;233:175-82. http://www.ncbi.nlm. nih.gov/pubmed/24990228 (accessed July 8, 2018).

8. Wang J, Xu K, Wu J, Luo C, Li Y,Wu X, Gao H, Feng G, Yuan $\mathrm{B}-Z$. The changes of Th17 cells and the related cytokines in the progression of human colorectal cancers. BMC Cancer. 2012; 12:418. doi:10.1186/1471-2407-12-418.

9. Ling L, Zhao P, Yan G, Chen M, Zhang T, Wang L, Jiang Y. The frequency of Th17 and Th22 cells in patients with colorectal cancer at pre-operation and post-operation. Immunol Invest. 2015;44:56-69. doi:10.3109/08820139.2014.936445.

10. Martin-Orozco N, Muranski P, Chung Y, Yang XO, Yamazaki T, Lu S, Hwu P, Restifo NP, Overwijk WW, Dong C. T helper 17 cells promote cytotoxic $T$ cell activation in tumor immunity. Immunity. 2009;31:787-98. doi:10.1016/j.immuni.2009.09.014.

11. Seebauer CT, Brunner S, Glockzin G, Piso P, Ruemmele P, Schlitt H-J, Geissler EK, Fichtner-Feigl S, Kesselring R. Peritoneal carcinomatosis of colorectal cancer is characterized by structural and functional reorganization of the tumor microenvironment inducing senescence and proliferation arrest in cancer cells. Oncoimmunology. 2016;5:e1242543. doi:10.1080 /2162402X.2016.1242543.

12. Amicarella F, Muraro MG, Hirt C, Cremonesi E, Padovan E, Mele V, et al. Dual role of tumour-infiltrating T helper 17 cells in human colorectal cancer. Gut. 2017;66:692-704. doi: 10.1136/gutjnl-2015-310016.

13. Lee JY, Seo E-H, Oh C-S, Paik J-H, Hwang D-Y, Lee SH, Kim S-H. Impact of circulating T helper 1 and 17 cells in the blood on regional lymph node invasion in colorectal cancer. J Cancer. 2017;8:1249-54. doi:10.7150/jca.18230.

14. Chen G, Zhang S, Pan S-B, Lyu Q-H, Wu P, Qin G-M, Wang Q, He Z-L, He X-M, Wu M. Postoperative regulatory T-cells and natural killer cells in stage I nonsmall cell lung cancer underwent video-assisted thoracoscopic lobectomy or thoracotomy. Chin Med J (Engl). 2015;128:1502. doi:10.4103/03666999.157672.

15. Fujii S, Tsukamoto M, Fukushima Y, Shimada R, Okamoto K, Tsuchiya T, Nozawa K, Matsuda K, Hashiguchi Y. Systematic review of laparoscopic vs open surgery for colorectal cancer in elderly patients. World J Gastrointest Oncol. 2016;8:573. doi: 10.4251/wjgo.v8.i7.573.

16. Trastulli S, Cirocchi R, Listorti C, Cavaliere D, Avenia N, Gullà N, Giustozzi G, Sciannameo F, Noya G, Boselli C. Laparoscopic $v s$ open resection for rectal cancer: a meta-analysis of 
randomized clinical trials. Colon Dis. 2012;14:e277-e296. doi: 10.1111/j.1463-1318.2012.02985.x.

17. Kang J, Baik SH, Lee KY, Sohn S-K. Outcomes of laparoscopic surgery in pathologic T4 colon cancers compared to those of open surgery. Int J Colorectal Dis. 2017;32:531-8. doi: 10.1007/s00384-016-2720-5.

18. Rubinkiewicz M, Migaczewski M, Hankus J, Dembiński M, Pẹdziwiatr M, Okoń K, et al. The number of regulatory Foxp3+ T-cells in different stages of malignant transformation of large intestinal polyps. Adv Med Sci. 2016;61:305-10. doi:10.1016/j. advms.2016.03.008.

19. Waniczek D, Lorenc Z, Śnietura M, Wesecki M, Kopec A, Muc-Wierzgoń M. Tumor-associated macrophages and regu- latory $\mathrm{T}$ cells infiltration and the clinical outcome in colorectal cancer. Arch Immunol Ther Exp (Warsz). 2017;65:445-54. doi:10.1007/s00005-017-0463-9.

20. Hu G, Li Z, Wang S. Tumor-infiltrating FoxP3+ Tregs predict favorable outcome in colorectal cancer patients: a meta-analysis. Oncotarget. 2017;8:75361-71. doi:10.18632/oncotarget.17722.

21. Gao H-J, Zhang Y-J, Liang H-H, Li P, Peng Z-W, Pang X-H, Chen M-S. Radiofrequency ablation does not induce the significant increase of CD4+CD25+Foxp3+ regulatory $\mathrm{T}$ cells compared with surgical resection in Hepal-6 tumor model. Arch Immunol Ther Exp (Warsz). 2013;61:333-40. doi: 10.1007/s00005-013-0226-1.

Sažetak

\section{PERIOPERACIJSKE PROMJENE SUBPOPULACIJA LIMFOCITA U BOLESNIKA OPERIRANIH ZBOG KOLOREKTALNOG KARCINOMA}

\section{Rubinkiewicz, I. Siemińska, P. Matczak, P. Major, J. Baran, A. Budzyński i M. Pędziwiatr}

Kirurški zahvat ima golem učinak na ravnotežu imunog sustava. Međutim, malo se zna o perioperacijskim promjenama u subpopulacijama $\mathrm{T}$ regulatornih i Th17 limfocita u bolesnika podvrgnutih resekciji kolorektuma. $\mathrm{U}$ istraživanje su bili uključeni bolesnici s resektabilnim karcinomom kolona. Uzorci krvi prikupljeni su dva puta: prije zahvata i dva dana nakon operacije. Uključena je bila i kontrolna skupina sastavljena od mladih i zdravih osoba. Subpopulacije limfocita analizirane su protočnom citometrijom. Istraživane su sljedeće subpopulacije: ukupan broj limfocita, CD4+, CD8+, T regulatorni Foxp3+ (Tregs), Th17 i bijela krvna slika. Utvrđene su značajne razlike u razinama imuno stanica prije i nakon operacije. Snižene razine zabilježene su za CD4+, CD8+, Tregs i ukupni broj limfocita ( $p=0,002, p=0,01, p=0,008$ odnosno $p=0,001)$. Povišenje je zapaženo za bijelu krvnu sliku i Th17 stanice, međutim, Th17 limfociti nisu postigli statističku značajnost ( $\mathrm{p}=0,01$ odnosno $\mathrm{p}=0,5)$. Zaključujemo da je kirurški zahvat uzrokovao promjene u svim istraživanim subpopulacijama limfocita kod bolesnika podvrgnutih operaciji kolorektalnog karcinoma. Međutim, čini se da je to bio učinak perioperacijske traume. Potrebna su daljnja istraživanja kako bi se ispitao utjecaj kirurškog zahvata na subpopulacije limfocita.

Ključne riječi: Subpopulacije limfocita; T-limfociti, regulacijski; Th17 stanice; Broj limfocita; Kolorektalna kirurgija 